\title{
A keresztcsonti ízület mobilitásának vizsgálata derékpanaszos betegcsoportban
}

\author{
Burkus Máté dr., ${ }^{1,2}$ - Márkus István dr. ${ }^{1}$ \\ Niklai Bálint dr. ${ }^{1}$ - Tunyogi-Csapó Miklós dr. ${ }^{1}$ \\ ${ }^{1}$ Pécsi Tudományegyetem, Általános Orvostudományi Kar, Klinikai Központ, Ortopédiai Klinika, Pécs \\ ${ }^{2}$ Petz Aladár Megyei Oktató Kórház, Balesetsebészeti és Kézsebészeti Osztály, Győr
}

A jelen tudományos közleményt a szerzők a Pécsi Tudományegyetem alapitásának 650. évfordulója tiszteletére közlik.

\begin{abstract}
Bevezetés: A medence sagittalis irányú megjelenésének leírására három paraméter használatos, amelyek között a medenceincidencia, meghatározás szerint, egyénre jellemző, anatómiai állandónak tekintett.

Célkitüzés: Jelen vizsgálat célja volt a medenceparaméterek vizsgálata egy olyan derékpanaszos heterogén csoportnál, ahol fizikálisan felmerült a keresztcsonti ízület mobilitásának lehetősége.

Módszer: 48, perzisztáló derékfájdalommal rendelkező eset álló, majd ülő EOS 2D/3D képalkotásából nyert medenceparaméter-értékeit hasonlítottuk össze a felső test helyzetének függvényében, klaszteranalízis, valamint t-próba használatával.

Eredmények: A medenceincidencia teljes betegcsoportra vonatkozó átlaga statisztikailag nem különbözött a két pozícióban $\left(47,8^{\circ}-47,7^{\circ}\right)$. Az egyéneket külön értékelő klaszteranalízis azonban 14 esetben $(30 \%)$ a felső test helyzetével összefüggő változást igazolt. Hét esetnél előrebillenő felső test, növekvő incidencia, hétnél ellenkező irányú változás mutatkozott, 34 esetben nem volt érdemi változás.

Következtetés: Tapasztalataink szerint a medence felnőttkorban sem tekinthető minden esetben merev egységnek. A populáció egy részében előfordulhat a keresztcsonti ízület mobilitása, amely összefüggést mutathat egyes, gerincet érintő deformációkkal, illetve a derékpanaszokkal.
\end{abstract}

Orv Hetil. 2017; 158(52): 2079-2085.

Kulcsszavak: EOS 2D/3D, medenceparaméterek, medenceincidencia, sagittalis irányú megjelenés

\section{Assessment of sacroiliacal joint mobility in patients with low back pain}

Introduction: Sagittal alignment of the pelvis is typically characterized using three fundamental parameters. Among these, pelvic incidence is traditionally considered to be anatomically 'constant'.

Aim: We aimed to analyze the pelvic parameters of low back pain patients with suspected sacroiliac joint laxity.

Method: Pelvic parameters were assessed in standing and seated EOS 2D/3D radiographs of 48 cases of persistent low back pain, and compared to upper body position using cluster analysis and t-test.

Results: Median pelvic incidence did not differ statistically between standing and sitting $\left(47.8^{\circ}-47.7^{\circ}\right)$. However, in individual analysis 7 cases (15\%) exhibited a forward tilt in their upper body with an increased pelvic incidence, and 7 cases (15\%) showed a backward upper body tilt. No change was found in 34 cases.

Conclusion: Our results indicate the pelvis should not be regarded as a rigid unit, as in some cases significant appreciable sacroiliac joint laxity can occur.

Keywords: EOS 2D/3D, pelvic parameters, pelvic incidence, sagittal alignment

Burkus M, Márkus I, Niklai B, Tunyogi-Csapó M. [Assessment of sacroiliacal joint mobility in patients with low back pain]. Orv Hetil. 2017; 158(52): 2079-2085.

(Beérkezett: 2017. augusztus 30.; elfogadva: 2017. október 19.) 


\section{Rövidítések}

$2 \mathrm{D}=$ kétdimenziós; $3 \mathrm{D}=$ háromdimenziós; $\mathrm{BMI}=($ body mass index) testtömegindex; CT = (computed tomography) komputertomográfia; PI = (pelvic incidence) medenceincidencia; $\mathrm{PV}=$ (pelvic version) medencedőlés; $\mathrm{SD}=$ standard deviáció; SS $=($ sacral slope $)$ keresztcsonti lejtés

A gerinc és a medence a tér mindhárom síkjában egymással szoros kapcsolatban álló egységet alkot, amelynek alapkövét maga a medence adja. A törzs sagittalis irányú egyensúlyáról, a medencének ebben betöltött szerepéről összetett információkkal rendelkezünk [1-5]. A medence oldalnézeti helyzete és megjelenése legjobban a Duval-Beaupère és Legaye által bevezetett három paraméter segítségével határozható meg. A keresztcsonti lejtés (sacral slope - SS; a keresztcsonti plató síkjának a vízszintessel bezárt szöge) és a medencedólés (pelvic version - PV; a combfejcentrumokat összekötő vonal középpontját a keresztcsontplató középpontjához kötő szakasznak a függólegessel bezárt szöge) a medence aktuális térbeli pozícióját írja le. A medenceincidencia (pelvic incidence - PI; a keresztcsont felső zárólemezének középpontjára állított meróleges és az ebből a pontból indított, szintén a combfejcentrumokat összekötő egyenes középpontjához vezető szakasz által bezárt szögérték) - feltételezve, hogy a sacroiliacalis ízületben csak mikromozgások vannak - egy egyénre jellemző anatómiai állandónak, így pozíciófüggetlen paraméternek tartott (1. ábra). A tanulmányok szerint ez a paraméter jellemzi leginkább a medence orientációját, így közvetetten a medence-gerinc egység kulcsfaktorának is tekinthető $[3,4]$.

Bár a jelenleg széles körben elfogadott definíció szerint a medenceincidencia értéke állandónak tekintendő, több tanulmány is felvetette változásának lehetőségét, például várandósság alatt. A terhességek többségében észlelt medenceövi fájdalom hátterében a medencében megjelenő fokozott mozgások valószínúsíthetők. Itt a hormonális változások miatt megnövekedett szalaglazaságok és a megváltozott biomechanikai állapotok a keresztcsontízületek mozgékonyságának fokozódását eredményezhetik $[6,7]$.

A medence helyzete legjobban a hozzá kapcsolt gerincszakaszra - vagyis az ágyéki lordosisra - van hatással $[5,8]$, de a koponyától egészen az alsó végtagokig megfigyelhető a kapcsolat, tehát a teljes gerinc alakja alkalmazkodik a medence helyzetéhez [9]. A csontos alkotók közti dinamikus kapcsolat kiegészül a lágyrészek aktív és passzív elemeivel, a test megfelelő egyensúlyának megtartása érdekében [5]. Ebben az összekapcsolt egységben a medenceincidencia értéke az, ami meghatározza a medence kompenzációs lehetőségeit. Magasabb PI-érték esetén nagyobb a keresztcsont dőlése, fokozottabbak a gerinc görbületei, így nagyobb a lehetőség az adaptáció$\mathrm{ra}$ is $[1]$.

A medenceincidencia értéke jól dokumentáltan változik a növekedés során. A gerinc fejlődése alatt minden sagittalis irányú paraméter fokozatos adaptálódást mutat, így szignifikánsan eltér a gyermek- és a felnőttpopulációk összehasonlításakor. Mangione és mtsai magzatokon, gyermekeken és felnőtteken történt összehasonlító vizsgálata során úgy találták, hogy az incidencia az élet első pár hónapjában jelentősen emelkedik, ami a járás megkezdése után egyenletesen folytatódik, végül 10 éves kor körül stabilizálódni látszik [10]. Mac-Thiong és mtsai lineáris növekedést figyeltek meg egészen 18 éves korig $[8,11]$. A növekedés esetén észlelt változásra magyarázatul szolgál a két lábon járáshoz való alkalmazkodás folyamata, majd a testarányok és testtömeg változásához való adaptáció. A gerinc melletti izmok, amelyek a keresztcsonton vastag inas lemezzel tapadnak, annak testét horizontalizációra kényszerítik, ezáltal a zárólemez előre, függőlegesebb helyzetbe billen. A farizmok, ezzel együtt a csípóízület felől forgatóan hatnak a medencére, tovább kényszerítve a keresztcsont billenését [10]. Egyes megfigyelések szerint a medence megjelenésére hatással lehet továbbá a testmagasság, testsúly vagy épp a csontkor is $[8,11]$.

$\mathrm{Az}$ incidencia értékének különbségei a medence-gerinc egységet érintő deformitások esetén is kimutatható. Gerincbetegségektől mentes kontrollpopulációhoz való viszonyítás során spondylolisthesissel rendelkező betegcsoportnál a PI értéke, valamint következményesen az ágyéki lordosis is emelkedettebbnek mutatkozott. Ilyenkor a keresztcsont teste horizontálisabb pozíciójú, zárólemeze függőlegesebb helyzetű, ami megváltozott ágyéki terhelést okoz. Ez az egyensúlyváltozás pedig hatással lehet az ágyéki csigolya további előrecsúszására is [1, 12-14]. Egyes szerzők valószínúsítik, hogy a megnövekedett medenceincidencia önmagában is szerepet játszhat a csigolyaelcsúszás kialakulásában [12]. Az ágyéki porckorongokat érintő elváltozásoknál, illetve porckorongsérvnél a megfigyelések a PI értékét a normálishoz nagyon hasonlónak vagy enyhén csökkentnek találták [1]. A csökkenés pedig kisebb ágyéki görbületet, egyenesebb gerincet eredményez, ami a porckorongok fokozott terheltségét jelenti $[14,15]$, valamint az ágyéki gerincfájdalom kialakulásával és fennmaradásával is kapcsolatba hozható [16]. Gerincferdülés mellett MacThiong és mtsai szignifikánsan magasabb medenceincidencia-értéket tapasztaltak [17]. Valószínúsítették, hogy scoliosisnál az észlelt emelkedés egy kompenzációváltozás eredménye, amellyel a szervezet növelni próbálja az ágyéki görbületet, hogy stabilizálja a test egyensúlyát, különösen háti görbület esetén.

A keresztcsonti ízület mobilitásának megítélésére alkalmazott fizikális vizsgálatok korlátozott eredményekkel használhatók, pontos és összetett képalkotás pedig számos esetben - mint várandósság vagy gyermekkor nem készíthető. Jelen vizsgálat során alkalmazott EOS 2D/3D (EOS Imaging, Párizs, Franciaország) egy képalkotó rendszer, a fizikai Nobel-díjas Georges Charpak röntgendetektálási elvén alapuló eszköz, amely forradalmi változást hozott a gerinc és az alsó végtagok rönt- 


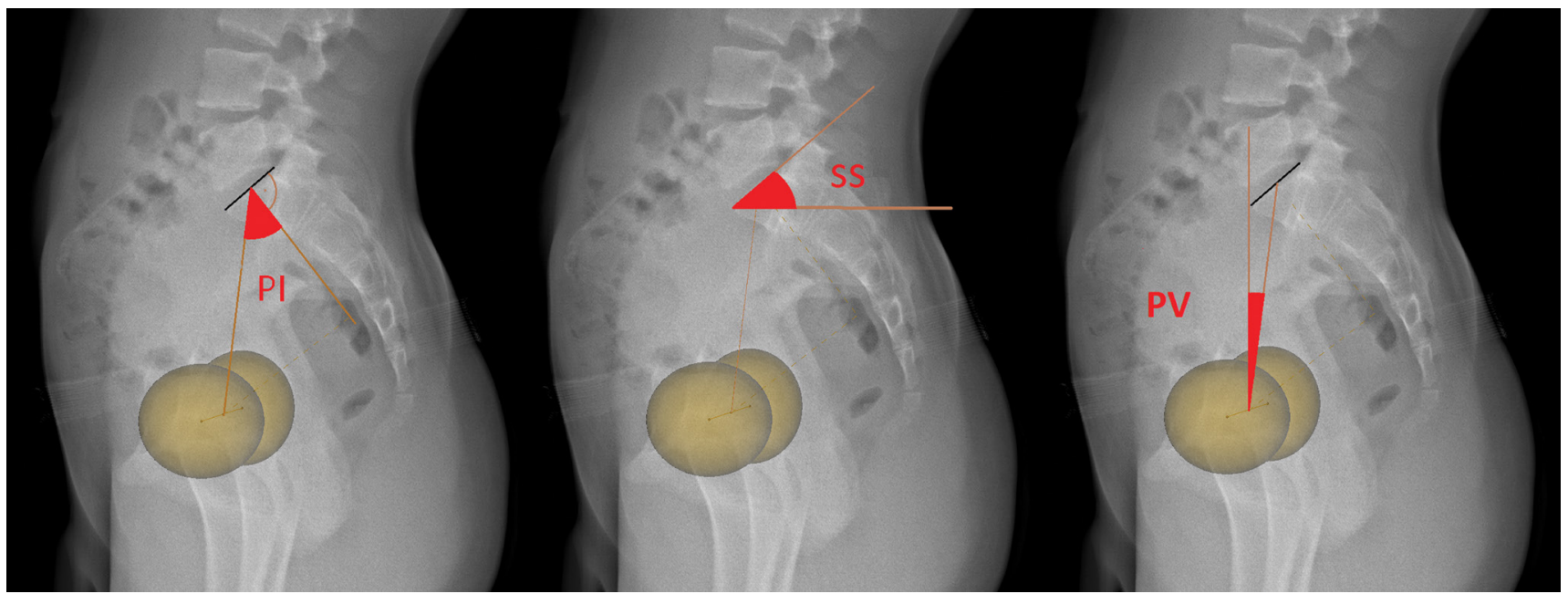

1. ábra

A medenceparaméterek. Medenceincidencia $(\mathrm{PI}=$ pelvic incidence $)$, keresztcsonti lejtés $(\mathrm{SS}=$ sacral slope $)$, medencedőlés $(\mathrm{PV}=$ pelvic version $)$. A medenceparaméterek között geometriai kapcsolat áll fenn (PV = PT + SS) [4]

genalapú értékelésében [18]. A készülék teljes terhelés mellett, álló helyzetben, szimultán végez anteroposterior és lateralis képalkotást, ultraalacsony sugárterhelés használatával. A kalibrált térben, standardizált beállítások mellett történő egész alakos képalkotás részletes kettős megjelenítést eredményez, amely lehetőséget ad, többek között, a gerinc és a medence körüli régió nagy pontosságú értékelésére. A számítógépesen létrehozott felületi modellek a CT-hez hasonló képet biztosítanak, annál lényegesen, akár több százszor kisebb sugárterheléssel [19-21]. A készülék, illetve a rekonstrukciós program pontosságát és a mindennapi ortopéd gyakorlatban való alkalmazhatóságát már számos vizsgálat bizonyította a gerinc, alsó végtagok, valamint a teljes medence-gerinc egység tekintetében, többek között intézetünkben is [22-29]. A kapott információk jó eredményekkel használhatók a gerincen végzett beavatkozásokon túl akár a csípöízületi protetika tervezésében vagy a beültetett implantátum helyzetének értékelésében, akár a standard álló testhelyzettől eltérő, ülő pozícióban is [30-32].

$\mathrm{Az}$ irodalom áttekintése és klinikai fizikális vizsgálatok során tapasztaltak alapján felmerült annak lehetősége, hogy bizonyos esetekben a derékpanaszok hátterében a keresztcsonti ízület fokozott mobilitása (a medenceincidencia értékének pozíciófüggő változása) is állhat. Kutatásunk céljául tüztük ki, hogy olyan derékpanaszos eseteknél, ahol a fizikális vizsgálat felvetette a keresztcsonti ízület fokozott mobilitási lehetőségét, azt nagy pontosságú röntgeneljárás használatával próbáljuk meg igazolni.

\section{Módszer}

Az általunk vizsgált betegek klinikánk járóbeteg-szakambulanciáján megjelent, rutin konzervatív kezelés ellenére perzisztáló ágyékigerinc-panaszokkal rendelkeztek, továbbá náluk a fizikális vizsgálat során felmerült a kereszt- csonti ízület mobilitása. Ezeknél a betegeknél elvégeztük a klinikai protokollnak megfelelő, álló helyzetű EOS 2D/3D képalkotáson kívül az eltérő testhelyzetű (ülő) leképezést is.

A vizsgálatba összesen 48 ( 15 férfi 33 nő) beteg került bevonásra, átlagéletkor: 19,9 év, megoszlás 16-30 év. A heterogén vizsgálati csoportban 18 esetnél (38\%) tapasztaltunk 20 fok feletti Cobb-szög-értékkel rendelkező gerincferdülést (átlag-Cobb-szög: 44 fok). További három esetben $(6 \%)$ enyhe gerincferdülés (Cobb-szög nem nagyobb, mint 20 fok) igazolódott. Három páciensnél (6\%) Scheuermann-betegség állt fenn. 24 esetnél (50\%) EOS-képalkotással kimutatható kóros állapot nem mutatkozott.

A röntgenvizsgálatokat megelőzően a páciensek vagy törvényes képviselőik írásos beleegyezésben járultak hozzá annak elvégzéséhez, illetve az adatok későbbi kutatási célú felhasználhatóságához.

A képanyagok feldolgozását a sterEOS 3D V1.3.4.3740 (EOS Imaging, Párizs, Franciaország) program segítségével végeztük. A rekonstrukciók elkészítését három egymástól függetlenül dolgozó, a program használatában nagy jártassággal rendelkező vizsgáló (PhD-hallgató és klinikai orvos) végezte. A vizsgálók a paraméterek meghatározását minden esetnél mindkét pozícióban, négy, egymástól független alkalommal végezték el. A statisztikai analízis során a mérések átlagát használtuk. A vizsgálók közti és az egy vizsgáló eredményein belüli megbízhatóság értékelése 20 random kiválasztott eset (10 álló, 10 ülő) három független alkalommal készült külön mérésével történt. Az eredmények közti kapcsolatot a Winer-kritériumok szerint értékeltük: 0-0,24-ig nincs vagy gyenge, 0,25-0,49-ig alacsony, 0,50-0,69-ig közepes, 0,7-0,89-ig jó, illetve 0,90-1,0-ig kitûnő [33].

$\mathrm{Az}$ esetek egy részénél a medenceincidencia eredményeit egyénenként nézve, a testhelyzet-változtatást követően, csökkenést, míg egy részénél növekedést figyeltünk 

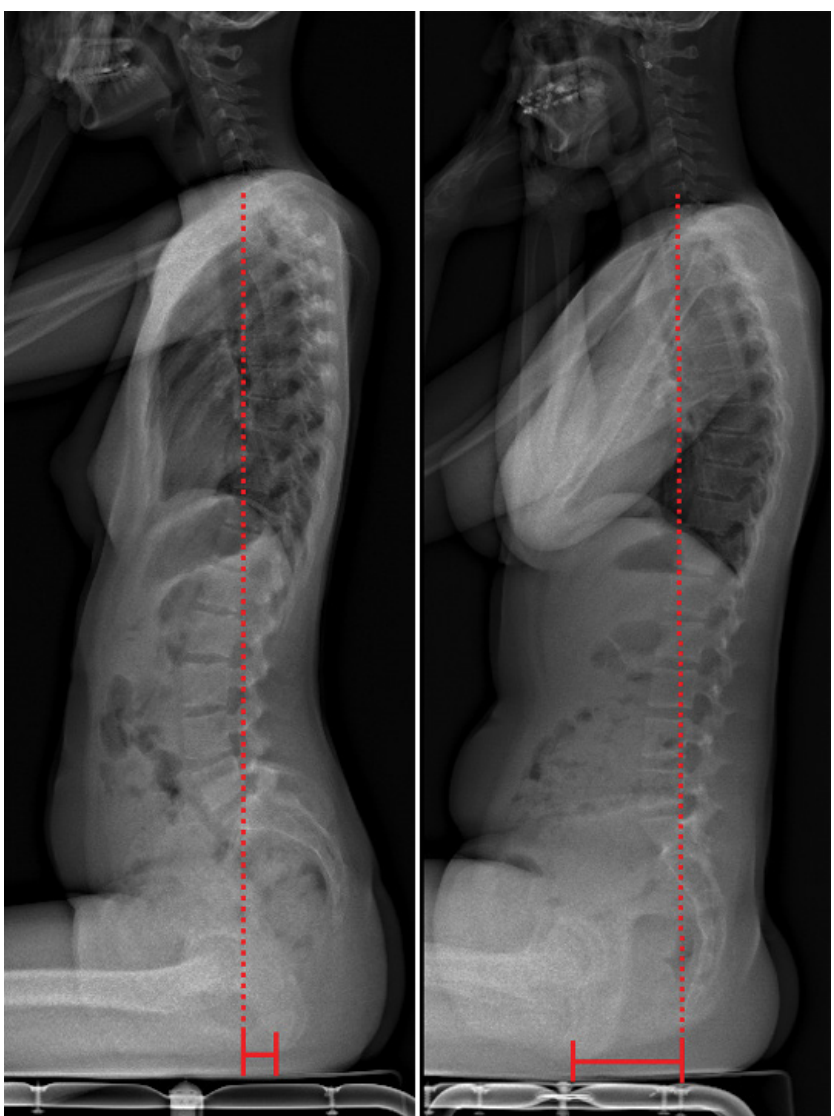

2. ábra

Az ülési pozíció értékelése. Az ülési pozíció értékelésére használt C7-súlyvonal-ülőgumók távolságának meghatározása, két eltérő esetnél. Abban az esetben, ha a felső test előrefelé dőlt (balra), a távolságot pozitívnak, ha hátrafelé dőlt (jobbra), negatívnak jegyeztük fel meg. A mindkét irányú (hol növekvő, hol csökkenő) változás okát keresve ismét áttekintettük a röntgenképeket, és azt tapasztaltuk, hogy a változás iránya, valamint az ülési pozíció között összefüggés mutatható ki. Ennek a megfigyelésnek az objektív mérésére nem találtunk megfelelő közlést az irodalomban, ezért - számos módszer kipróbálását követően - a C7-es csigolya testének középpontjára állított függőleges tengely (az oldalnézeti C7súlyvonal), mint a felső test helyzetének indikátora, és az alátámasztási pontnak tekintett ülőgumók (tuber ischiik) legalacsonyabb pontja közötti távolság mérésével tudtuk relevánsan számszerüsíteni a pozíciót (2. ábra).

A kapott adatok feldolgozását az SPSS v22 (IBM Corp., Armonk, NY, Amerikai Egyesült Államok) és Microsoft Office Professional Plus vl4.0.6112.5000 (Microsoft Corp., Redmond, WA, Amerikai Egyesült Államok) programcsomagokkal végeztük. Az üló-álló csoport paraméterei közti kapcsolatot független mintás, illetve páros mintás t-próbával értékeltük. A medenceincidencia-értékek különbségeit az ülési pozíció függvényében klaszteranalízissel vizsgáltuk. Az eredmények értékelése során a $\mathrm{p}<0,05$ értéket tekintettük szignifikánsnak.

\section{Eredmények}

A vizsgálat során a mérési eredmények megbízhatósága, mind a vizsgálok között, mind az egyes vizsgálók eredményein belül 0,85 és 0,95 közötti értéket adtak a Winer-kritériumok szerint, így jónak, illetve kitűnőnek mutatkoztak.

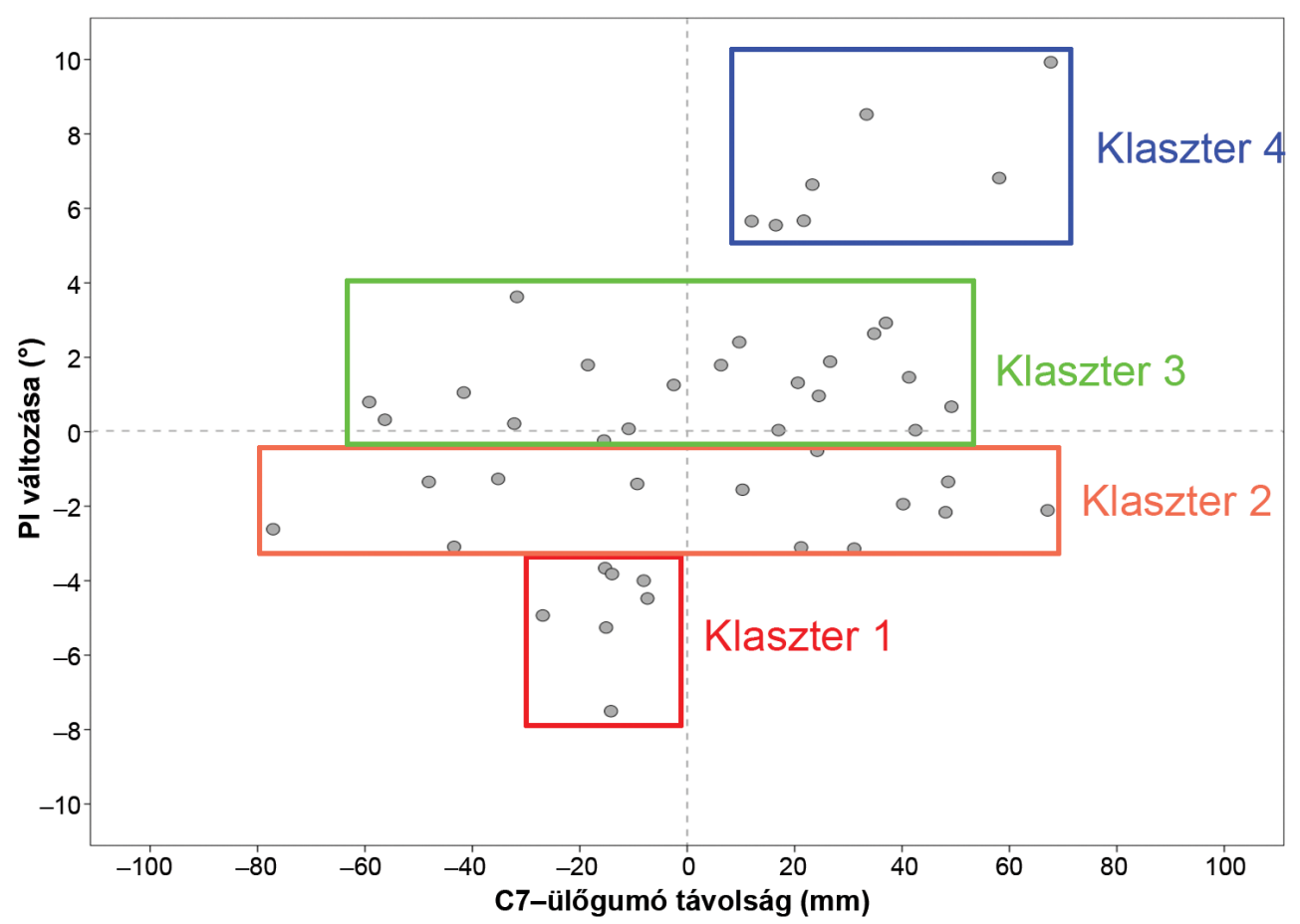


1. táblázat | Összesített medenceparaméter-értékek. A feldolgozott esetek nél tapasztalt medenceparaméterek átlaga, standard deviációja valamint a páros mintás t-teszttel végzett statisztikai kapcsolata

\begin{tabular}{llll}
\hline Paraméter & Álló átlag \pm SD & Ülő átlag \pm SD & t-próba \\
\hline PI & $47,8 \pm 11,5$ & $47,7 \pm 12,8$ & $\mathrm{p}=0,898$ \\
SS & $39,8 \pm 9,9$ & $25,7 \pm 11,9$ & $\mathrm{p}<0,001$ \\
PV & $7,9 \pm 6,2$ & $22,5 \pm 13,5$ & $\mathrm{p}<0,001$ \\
\hline
\end{tabular}

PI = medenceincidencia $;$ PV = medencedőlés $;$ SD = standard deviáció; SS $=$ keresztcsonti lejtés

A medenceparaméterek összesített eredményeit az 1 . táblázatban foglaltuk össze. Az álló és ülő helyzetű felvételeken mért medenceincidencia-értékek teljes vizsgálati csoportra vonatkozó összesített átlagai között nem volt szignifikáns eltérés, mivel a pozitív és negatív irányú eltérések kiegyenlítették egymást. A PI-eredményeket egyénenként megvizsgálva, az eltérő testhelyzeti átlagértékek között, $7,6^{\circ}$-os csökkenést és $9,9^{\circ}$-os növekedést is tapasztaltunk (átlagos eltérés: $\pm 2,8^{\circ}$ ).

Klaszteranalízist végeztünk, hogy megállapítsuk, elkülönülnek-e az instabilitással rendelkező esetek abban az esetben, ha figyelembe vesszük a felső test helyzetét (C7-ülőgumó távolság). Az individuális (álló és ülő helyzeti) medenceincidencia-értékek különbséget, valamint a C7-súlyvonalnak az ülőgumókhoz viszonyított távolságait nézve a klaszteranalízis négy csoportot különített el (3. ábra):

- Az első klaszterben helyezkednek el azok az esetek, ahol jelentősebb csökkenés volt megfigyelhető a medenceincidencia értékében, továbbá az ülő helyzeti képen a C7 súlyvonala az ülőgumók mögött helyezkedett el (vagyis leülést követően a felső test helyzetben hátrafelé dőlt, amely során a PI csökkent - 2. ábra, jobb oldal). A csoportba hét eset (15\%) került, itt kettőnél 20 fok feletti, további két esetnél 20 fok alatti Cobb-szög-értékű gerincferdülés volt kimutatható, három eset pedig elváltozás nélkülinek bizonyult.

- A második és harmadik klaszter azokat az eseteket foglalta magába, ahol a PI-értékeknek változásai a testhelyzet dőlésétől függetlenül nem volt szignifikáns. Ezt a két csoportot stabilnak jelöltük, így összevonhatók (34 eset, 70\%). Közülük 13 rendelkezett 20 fok feletti Cobb-szög-értékű gerincferdüléssel, további három eset Scheuermann-betegséggel, 18-nál pedig sem gerinc-, sem medenceérintettség nem volt igazolható.

- A negyedik klaszterbe kerültek azok az esetek, ahol a felső test előredőlését tapasztaltuk, amely a medenceincidencia értékének növekedését okozta (2. ábra, bal oldal). Ebbe a csoportba szintén hét eset (15\%) tartozott. Itt háromnál 20 fok feletti, további egynél 20 fok alatti Cobb-szög-értékű gerincferdülés volt kimutatható, míg három eset elváltozás nélkülinek mutatkozott.

A klaszteranalízis során kapott csoportokat külön kezelve, mindegyiknél elvégeztük az álló és ülő helyzetben mért medenceincidencia-értékek páros mintás t-próbá- val való összehasonlítását. Az első és negyedik csoportban szignifikáns különbséget találtunk a két helyzetben mért paraméterek között $(\mathrm{p}<0,001$, átlagok különbsége $4,83^{\circ}$, illetve $6,95^{\circ}$ ), míg az összevont, stabil csoportban (klaszter 2,3 ) statisztikai eltérés nem igazolódott ( $\mathrm{p}=$ 0,785 , különbség $0,09^{\circ}$ ).

\section{Megbeszélés}

A medence sagittalis irányú megjelenésének meghatározására a Duval-Beaupère és Legaye által bevezetett három fó medenceparaméter használatos. Definíciójuk szerint a medencedőlés és a keresztcsonti lejtés pozicionálisnak, míg a medenceincidencia egy egyénre jellemző anatómiai állandónak tartott $[3,4]$. Pozíciófüggő változását eddig csak várandósság alatt figyelték meg $[6,7]$. A PI értéke a normális növekedési folyamat során bizonyítottan változik $[8,10,11]$, valamint egyes gerincdeformitások esetén is különbözik $[1,12-14,17]$. Jelen vizsgálat céljaként a szerzők a medenceincidencia pozíciófüggő változásának és azoknak a derékpanaszokhoz való viszonyának az értékelését tüzték ki.

A vizsgálat során alakalmozott EOS 2D/3D képalkotó rendszernek az álló pozíciótól eltérő (ülő testhelyzetű) használhatóságát korábban már több szerző is igazolta. Lazennec és mtsai az EOS-készüléket a konvencionális röntgenképalkotással összehasonlítva (mind álló, mind ülő pozícióban) kellöen pontosnak, illetve ismételhetőségében még jobbnak találták [31]. Bendaya és mtsai, valamint Loppini és mtsai a csípőprotézis vápahelyzetének értékeléséhez használtak álló és ülő helyzetű EOS-felvételeket. Az értékek ismételhetőségét jónak, 3 foknál kisebb eltérésűnek találták, illetve vizsgálatuk során a medenceincidenciával szignifikáns kapcsolatot igazoltak $[30,32]$.

Jelen vizsgálat összesített eredményeiben, eltérő testhelyzetek esetén, a pozicionális medencedőlés és keresztcsonti lejtés különbözött csak szignifikánsan, míg a medenceincidencia átlaga - mivel a negatív és pozitív irányú változások kiegyenlítették egymást - nem tért el. Ez alapján a teljes populációra vonatkozóan a PI-értékek valóban nem különböznek szignifikánsan a testhelyzet függvényében.

Azonban az eredményeket egyénenként külön vizsgálva, már jelentős pozíciófüggő különbségek voltak kimutathatók. A felvételeket áttekintve a változás iránya az ülési pozícióval is összefüggésbe hozhatónak bizonyult, ennek számszerüsítésére a C7-súlyvonal és az ülőgumók közti távolság került megahatározásra. Az eredményeket figyelembe véve a klaszteranalízis négy csoportot különített el. Az első csoportnál ülő helyzetben a C7-súlyvonal az ülőgumók mögé esett (hátradőlt páciens) és a keresztcsonti ízület mobilitást mutatott, a medence incidenciaértéke csökkent (az esetek 15\%-a). A második csoportnál a súlyvonal az ülőgumók elé esett és az ízületben instabilitás volt, a PI-érték növekedése igazolódott (szintén az esetek 15\%-a). A további két csoportot, ahol szignifikáns 
változás nem volt kimutatható, stabil keresztcsonti ízülettel rendelkezőnek tekintettük (az esetek 70\%-a). A változást nem mutató összevont csoportban előfordulhatott olyan eset jelenléte, ahol a súlyvonal és a támaszkodási pont ülő pozícióban sem változott érdemben (tehát a test sem előre, sem hátra nem dőlt), így bár a keresztcsonti ízületben lehetett mobilitás, azt mégsem tudtuk kimutatni.

Arra, hogy egyénenként több esetben volt változás a medenceincidencia értékében, míg az összesített átlag érdemben nem különbözött, magyarázatul szolgálhat, hogy a vizsgálat során közel egyező számban és mértékben tapasztaltuk a medenceincidencia értékének csökkenését és növekedését is. A mindkét irányba mutató egyenlő számú és közel egyenlő mértékű változás oka ismeretlen, az valószínúleg a véletlennek tudható be.

Az általunk vizsgált jelenséggel, a keresztcsontízületek mobilitási lehetőségével korábban már Legaye és mtsai is foglalkoztak, de vizsgálatukban annak mértékét elhanyagolhatónak értékelték [34]. A jelen összehasonlítás során alkalmazott és bizonyítottan nagy pontosságú, valamint megbízható képalkotásra alapozva a szerzők feltételezik, hogy a megfigyelt változás néhány esetben mégsem elhanyagolható.

$\mathrm{Az}$ észlelt keresztcsonti ízületi mobilitás hátterében felmerült a gyanú, hogy az kapcsolatba hozható bizonyos medence-gerinc egységet érintő betegségekkel. Gerincbetegségek (többek között gerincferdülés) jelenléte mellett számos szerző észlelt a kontrollcsoporttól eltérő medenceincidencia-értéket, ami feltételezi, hogy a medence alkalmazkodhat a megváltozott állapothoz, és a keresztcsonti ízületi mozgásnak szerepe lehet a deformitás kialakulásában. A betegségek esetén tapasztalt eltérő értékek eredetéról az irodalomban bővebb információk nem érhetőek el, így nem ismert, hogy a különbségek fokozatosan alakulnak ki vagy egy azonnal ható, dinamikus komponens állhat a háttérben, úgymint fennmaradt keresztcsonti mobilitás, esetleg a kettő együttesen.

A vizsgálat beteganyagát tekintve, a 48 feldolgozott eset közül 2l-nél (44\%) volt jelen gerincferdülés mint alapbetegség. Amennyiben a scoliosis és a keresztcsonti ízület mobilitásának kapcsolatát tekintjük, a 14, változást mutató esetból nyolcnál (57\%), míg a 34, stabilnak mutatkozó közül 13-nál (38\%) tapasztaltuk az elváltozást, ami szignifikáns különbséget nem jelentett, így az észlelt mobilitás háttereként csupán a gerincferdülést mint alapbetegséget megnevezni nem tudtuk.

A tapasztaltak hátterében akár összetett élettani folyamatoknak is szerepe lehet, hasonlóan a várandósság során észleltekhez. Ott a medence - jellemzően fájdalmas panaszokat is okozó mozgásának okaként - a megváltozott hormonális állapotot és a terhelést feltételezik. $\mathrm{Az}$ általunk vizsgált eseteknél várandósság bizonyítottan nem állt fenn, de más okból történt hormonális állapotváltozással kapcsolatban információval nem rendelkeztünk, így azt kizárni sem tudtuk.
A jelen vizsgálatba bevont 48 esetünkben a fizikális vizsgálattal megállapított keresztcsonti mobilitás radiológiailag csak 14 esetben (30\%) igazolódott. A feldolgozott esetek kivétel nélkül derékpanaszokkal is rendelkeztek, így feltételezhető, hogy a tapasztalt mobilitás kapcsolatba hozható az ágyéki gerincfájdalommal, bár az egyértelmű összefüggés, megfelelő kontrollcsoport hiányában, szintén nem volt egyértelmüen bizonyítható.

A vizsgálat eredményeit limitálja továbbá a kis esetszám, valamint a nem homogén betegcsoport, ahol mind gerincelváltozással rendelkező, mind a nélküli esetek is feldolgozásra kerültek.

A jelenség pontos igazolásához és megértéséhez a későbbiekben nagyobb esetszámmal és homogén csoportnál végzett összehasonlítások szükségesek, amelyek kitérhetnek a test sagittalis irányú egyensúlyának célzott változtatására, például a felső test kontrollált előre és hátra történő hajtásával.

Jelen tanulmány konklúziójaként felvetődik, hogy a populáció egy részében fennállhat a keresztcsonti ízület fokozott mobilitása, amely összefüggésben lehet a medence-gerinc egységet érintő elváltozásokkal, többek között az ismeretlen eredetű derékfájdalommal.

Anyagi támogatás: A szerzők anyagi támogatásban nem részesültek.

Szerzôi munkamegosztás: B. M.: A kutatási terv elkészítése, a felvételek összegyüjtése, a vizsgálat lefolytatása, statisztikai elemzés, a kézirat megszövegezése. M. I., N. B.: A vizsgálat lefolytatása, statisztikai elemzés. T.-Cs. M.: A hipotézis felállítása, a kutatási terv ellenőrzése, ambuláns betegvizsgálat, a felvételek összegyưjitése, a kézirat megszövegezése. A cikk végleges változatát valamennyi szerző elolvasta és jóváhagyta.

Érdekeltségek: A szerzőknek nincsenek érdekeltségeik.

\section{Köszönetnyilvánítás}

A szerzók köszönetüket fejezik ki Illés Tamás professzor úrnak a klinikai alapprobléma felvetéséért, a vizsgálatsorozat megtervezéséért és a kézirattal kapcsolatos kritikai észrevételeiért. Továbbá köszönik $D r$. Somoskeöy Szabolcsnak a vizsgálatsorozat kivitelezésében és az adatok statisztikai elemzésében való részvételét, valamint $D r$. Schlégl Ádám Tibornak a kézirat megszövegezéséhez és a statisztika elkészítéséhez nyújtott segítségét.

\section{Irodalom}

[1] Barrey C, Jund J, Noseda O, et al. Sagittal balance of the pelvisspine complex and lumbar degenerative diseases. A comparative study about 85 cases. Eur Spine J. 2007; 16: 1459-1467.

[2] Boulay C, Tardieu C, Hecquet J, et al. Sagittal alignment of spine and pelvis regulated by pelvic incidence: standard values and prediction of lordosis. Eur Spine J. 2006; 15: 415-422.

[3] Duval-Beaupère G, Schmidt C, Cosson P. A Barycentremetric study of the sagittal shape of spine and pelvis: the conditions re- 
quired for an economic standing position. Ann Biomed Eng. 1992; 20: 451-462.

[4] Legaye J, Duval-Beaupère G, Hecquet J, et al. Pelvic incidence: a fundamental pelvic parameter for three-dimensional regulation of spinal sagittal curves. Eur Spine J. 1998; 7: 99-103.

[5] Roussouly P, Pinheiro-Franco JL. Biomechanical analysis of the spino-pelvic organization and adaptation in pathology. Eur Spine J. 2011; 20(Suppl 5): 609-618.

[6] Aldabe D, Milosavljevic S, Bussey MD. Is pregnancy related pelvic girdle pain associated with altered kinematic, kinetic and motor control of the pelvis? A systematic review. Eur Spine J. 2012; 21: 1777-1787.

[7] Van Kessel-Cobelens AM, Verhagen AP, Mens JM, et al. Pregnancy-related pelvic girdle pain: intertester reliability of 3 tests to determine asymmetric mobility of the sacroiliac joints. J Manipulative Physiol Ther. 2008; 31: 130-136.

[8] Mac-Thiong JM, Berthonnaud E, Dimar JR 2nd, et al. Sagittal alignment of the spine and pelvis during growth. Spine 2004; 29 : 1642-1647.

[9] Kobayashi T, Atsuta Y, Matsuno T, et al. A longitudinal study of congruent sagittal spinal alignment in an adult cohort. Spine 2004; 29: 671-676.

[10] Mangione P, Gomez D, Senegas J. Study of the course of the incidence angle during growth. Eur Spine J. 1997; 6: 163-167.

[11] Mac-Thiong JM, Labelle H, Berthonnaud E, et al. Sagittal spinopelvic balance in normal children and adolescents. Eur Spine J. 2007; 16: 227-234.

[12] Labelle H, Roussouly P, Berthonnaud E, et al. Spondylolisthesis, pelvic incidence, and spinopelvic balance: a correlation study. Spine 2004; 29: 2049-2054.

[13] Marty C, Boisaubert B, Descamps H, et al. The sagittal anatomy of the sacrum among young adults, infants, and spondylolisthesis patients. Eur Spine J. 2002; 11: 119-125.

[14] Vaz G, Roussouly P, Berthonnaud E, et al. Sagittal morphology and equilibrium of pelvis and spine. Eur Spine J. 2002; 11: 8087.

[15] Roussouly P, Gollogly S, Berthonnaud E, et al. Classification of the normal variation in the sagittal alignment of the human lumbar spine and pelvis in the standing position. Spine 2005; 30: 346-353.

[16] Illés ST. Low back pain: when and what to do. [A derékfájás: mikor és mit tegyünk?] Orv Hetil. 2015; 156: 1315-1320. [Hungarian]

[17] Mac-Thiong JM, Labelle H, Charlebois M, et al. Sagittal plane analysis of the spine and pelvis in adolescent idiopathic scoliosis according to the coronal curve type. Spine 2003; 28: 1404 1409.

[18] Charpak G. Prospects for the use in medicine of new detectors of ionizing radiation. Bull Acad Natl Med. 1996; 180: 161-168.

[19] Than P, Szuper K, Somoskeöy S, et al. Geometrical values of the normal and arthritic hip and knee detected with the EOS imaging system. Int Orthop. 2012; 36: 1291-1297.

[20] Gheno R, Nectoux E, Herbaux B, et al. Three-dimensional measurements of the lower extremity in children and adolescents using a low-dose biplanar X-ray device. Eur Radiol. 2012; 22 : 765-771.
[21] Dietrich TJ, Pfirrmann CW, Schwab A, et al. Comparison of radiation dose, workflow, patient comfort and financial break-even of standard digital radiography and a novel biplanar low-dose $\mathrm{X}$-ray system for upright full-length lower limb and whole spine radiography. Skeletal Radiol. 2013; 42: 959-967.

[22] Szuper K, Schlégl ÁT, Leidecker E, et al. Three-dimensional quantitative analysis of the proximal femur and the pelvis in children and adolescents using an upright biplanar slot-scanning X-ray system. Pediatr Radiol. 2015; 45: 411-421.

[23] Illés T, Somoskeöy S. Principles of the EOS ${ }^{\mathrm{TM}} \mathrm{X}$-ray machine and its use in daily orthopedic practice. [Az EOS ${ }^{\mathrm{TM}}$ röntgengép elve és gyakorlati használata a mindennapi ortopédiai gyakorlatban.] Orv Hetil. 2012; 153: 289-295. [Hungarian]

[24] Illés T, Somoskeöy $S$. The EOS ${ }^{\mathrm{TM}}$ imaging system and its uses in daily orthopaedic practice. Int Orthop. 2012; 36: 1325-1331.

[25] Schlégl ÁT, Szuper K, Somoskeöy S, et al. Evaluation of the usefulness of the EOS 2D/3D system for the measurement of lower limbs anatomical and biomechanical parameters in children. [Az EOS 2D/3D System alkalmazhatóságának vizsgálata a szabad alsó végtag anatómiai és biomechanikai paramétereinek mérésére gyermekkorban.] Orv Hetil. 2014; 155: 1701-1712. [Hungarian]

[26] Schlégl ÁT, Szuper K, Somoskeöy S, et al. Three dimensional radiological imaging of normal lower-limb alignment in children. Int Orthop. 2015; 39: 2073-2080.

[27] Schlégl ÁT, O'Sullivan I, Varga P, et al. Determination and correlation of lower limb anatomical parameters and bone age during skeletal growth (based on 1005 cases). J Orthop Res. 2016; 35: 1431-1441.

[28] Wybier M, Bossard P. Musculoskeletal imaging in progress: the EOS imaging system. Joint Bone Spine 2013; 80: 238-243.

[29] Lazennec JY, Brusson A, Folinais D, et al. Measuring extension of the lumbar-pelvic-femoral complex with the $\mathrm{EOS}^{\circledast}$ system. Eur J Orthop Surg Traumatol. 2015; 25: 1061-1068.

[30] Bendaya S, Anglin C, Lazennec JY, et al. Good vs poor results after total hip arthroplasty: an analysis method using implant and anatomic parameters with the EOS imaging system. J Arthroplasty 2016; 31: 2043-2052.

[31] Lazennec JY, Rousseau MA, Rangel A, et al. Pelvis and total hip arthroplasty acetabular component orientations in sitting and standing positions: measurements reproductibility with EOS imaging system versus conventional radiographies. Orthop Traumatol Surg Res. 2011; 97: 373-380.

[32] Loppini M, Longo UG, Ragucci $P$, et al. Analysis of the pelvic functional orientation in the sagittal plane: A radiographic study with EOS 2D/3D technology. J Arthroplasty 2017; 32: 10271032.

[33] Winer BJ. Statistical principles in experimental design. 2nd ed. McGraw-Hill, New York, 1971.

[34] Legaye J, Duval-Beaupère G. Sagittal plane alignment of the spine and gravity: a radiological and clinical evaluation. Acta Orthop Belg. 2005; $71: 213-220$.

(Burkus Máté dr., Györ, Vasvári Pál u. 2-4, 9023 e-mail: burkusmate@gmail.com)

Az Orvosi Hetilap egyes számai megvásárolhatók a Mediprint Orvosi Könyvesboltban. Cím: Budapest V., Múzeum krt. 17. - Telefon: 317-4948 